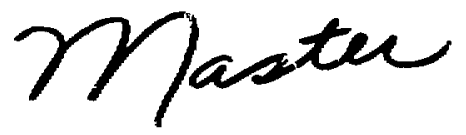
Distribution Category:
Gas Cooled Reactor Technology (UC-77)

ANL/MSD-80-8

ARGONNE NATIONAL LABORATORY

9700 South Cass Avenue

Argonne, Illinois 60439

REVIEW OF CURRENT FAACTICES AND REQUIREMENTS

FOR THE INSPECTION OF

PRESTRESSED CONCRETE PRESSURE VESSELS

by

K. J. Reimanz

Materials Science Division

December 1980 
ABSTRACT .............................. 1

I. INTRODUCTION ....................... 1

II. ASME CODE REQUIREMENTS .................... 1

III. PRACTICES IN CONSTRUCTION AND OPERATION OF GAS-COOLED REACTOR VESSELS ....................... 5

IV. DISCUSSION AND RECOMMENDATIONS ............... 6

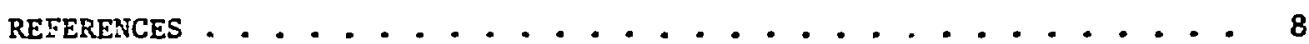

LIST OF TABLES

No.

I. Testing Frequencies for Concrete Material and Concrete . . . . 3

II. Examination Methods for CRV Components and Parts . . . . . . 4 III. PCRV Structural Instrumentation ................ 5 


\title{
REVIEW OF CURRENT PRACTICES AND REQUIREMENTS FOR THE INSPECTION OF PRESTRESSED CONCRETE PRESSURE VESSELS
}

\author{
K.J. Ræimann
}

\begin{abstract}
Code requirements for pre- and in-service inspection of prestressed concrete pressure vessels as utilized in gas-gooled reactors are reviewed and compared with practices and experiences during construction, commissioning, and operation of such reactors. The pre-service inspection relies heavily on embedded instrumentation for measurements of stresses, temperatures, and displacements. The same instrumentation is later used for in-service surveillance, which additionally includes visual examination of exposed surfaces, monitoring of tendon conditions, and measurement of tendon loads. Improvement of present monitoring instrumentation and/or techniques, rather than development of new in-service inspection methods, is recommended.
\end{abstract}

\section{INTRODUCTION}

The unique feature that differentiates gas-cooled reactors from other nuclear reactor types is the primary pressure vessel, which is fabricated of prestressed concrete. According to the rules of the ASME Boiler and Pressure Vessel Code, such a vessel is classified as a class 1 component. Whilo rules for metallic class 1 components existed when construction of gas-cooled reactors was initiated, similar rules for prestressed-concrete class 1 components had to be developed and implemented. These rules evolved in part from practices and requirements of various organizations dealing with prestressed concrete, and in part from experience gained in the U.S. and abroad from the construction and oferation of prototype gas-cooled reactors.

A literature review of current practices and requirements was conducted in order to assess the needs for development of additional in-service inspection techniques. The present report summarizes the findings and discusses areas where additional efforts would be beneficial.

\section{ASME CODE REQUIREMENTS}

The requirements for the construction of prestressed concrete nuclear pressure vessels, including inspection requirements, are contained in Section III, Division ${ }^{(1)}$ of the ASME Boiler and Pressure Vessel Code. This code became mandatory on July 1, 1975. Section III, Division 2 does not cover post-construction requirements. These requirements, related specifically to in-service inspection, are covered in ASME Code Section XI, Division 2.(2) The latter code section, however, is not yet mandatory. 
Other countries involved in gas-cooled reactor technology, such as Great Britain, France, and West Germany, have developed their owr prestressed concrete pressure vessel requirements in the form of specifications, decrees, or study reports.

While there are many similarities among these documents, there are also some differences. (3) The ASME Code is unique in that it requires owners, constructors, and fabricators to be certified (Section III, Division 2, Subsection $(\mathrm{CA})$. Certification means in this case that quality assurance programs of the various participants satisfactorily meet all code requirements. Subsection $C B$ of Section III, Division 2 addresses the rules and requirements for concrete reactor vessels. It covers areas such as materials specification and testing, design criteria, fabrication and construction requirements, construction testing and examination, and structural integrity tests of reactor vessels. The articles on materials, fabrication, and construction specify in detail not only the requirements for concrete but also for reinforcing and prestressing systems and liner materials. From a nondestructive sesting viewpoint, only the articles on construction testing and examination and structural integrity testing of concrete reactor vessels are of interest. Table I (from Ref. 1) summarizes the required tests for concrete material during construction. These tests do not, in general, fall within the scope of routine NDE methods.

The structural integrity test performed on concrete reactor vessels after completion of the construction phase is the final acceptance test. The code requires a pressure test at 1.15 times the design pressure. The following are required prior to, during, and after the test:

(a) A visual examination of accessible exterior surfaces for surface cracking.

(b) Deflection measurements of tha structure.

(c) Strain measurements inside and on the surface of the structure.

(d) Tendon force measurements.

(e) Tempirature measurements.

(f) Pressure measurements.

If the measurements remain within specified percentages of predicted maximum values, the pressure vessel is accepted. The only routine NDE procedure required for the inspection of prestressed concrete pressure vessels by Section III, Division 2 of the ASLE Code are visual examination and instrumentation measurements.

The rules and regulations for in-service inspection of concrete reactor vessels are covered in ASME Code Section XI, Division 2, Subsection IGX. This subsection makes a distinction tetween in-service examination and inservice monitoring and surveillance. The examination methods recomended for concrete reactor vessels are shown in Table II, (2) 
TABLE I

TESTNNG FREQUENCIES FOR CONCRETE MATERIAL AND CONCRETE a

\begin{tabular}{|c|c|c|c|}
\hline Material & Requirements & Test Mothod & Frequency \\
\hline Cement & $\begin{array}{l}\text { Standard physical and chemical } \\
\text { properties }\end{array}$ & ASTM C 150 & Each 1200 tons \\
\hline $\begin{array}{l}\text { Fly Ash and } \\
\text { Pozzolans }\end{array}$ & $\begin{array}{l}\text { Chemical and physical proper- } \\
\text { ties in accordance with } \\
\text { ASTM C } 618\end{array}$ & ASTM C 311 & Each 200 tons \\
\hline Aggregate & $\begin{array}{l}\text { Gradation } \\
\text { Moisture content } \\
\text { Material finer than } \$ 200 \text { sieve } \\
\text { Organic impurities } \\
\text { Flat and elongated particles } \\
\text { Friable particles } \\
\text { Lightweight parnicles } \\
\text { Soft fragments } \\
\text { Specific gravity and absorption } \\
\text { Los Angeles abrasion } \\
\text { Potential reactivity } \\
\text { Soundness }\end{array}$ & $\begin{array}{l}\text { ASTM C } 136 \\
\text { ASTM C } 566 \\
\text { ASTM C } 117 \\
\text { ASTM C } 40 \\
\text { CRDC } 119 \\
\text { ASTM C } 142 \\
\text { ASTM C } 123 \\
\text { ASTM } 235 \\
\text { ASTM C } 127 \text { or } \\
\text { ASTM C } 128 \\
\text { ASTM C } 131 \text { or } \\
\text { ASTM C } 535 \\
\text { ASTM C } 289 \\
\text { ASTM C } 88\end{array}$ & $\begin{array}{l}\text { Once daily during production' } \\
\text { Twice daily during production } \\
\text { Daily during production } \\
\text { Daily during production } \\
\text { Monthly during production } \\
\text { Monthly during production } \\
\text { Monthly during production } \\
\text { Monthly during production } \\
\text { Monthly during production } \\
\text { Every } 6 \text { months } \\
\text { Every } 6 \text { months } \\
\text { Every } 6 \text { months }\end{array}$ \\
\hline Water and lce & $\begin{array}{l}\text { Compliance with CB-2223 } \\
\text { Effect on compressive strength } \\
\text { Setting time } \\
\text { Soundness } \\
\text { Total solids } \\
\text { Chlorides }\end{array}$ & $\begin{array}{l}\text { ASTM C } 109 \\
\text { ASTM C } 191 \\
\text { ASTM C } 151 \\
\text { ASTM D } 1888 \\
\text { ASTM D } 512\end{array}$ & $\begin{array}{l}\text { Monthly } \\
\text { Monthly } \\
\text { Monthiy } \\
\text { Monthly } \\
\text { Monthly }\end{array}$ \\
\hline Admixtures & Chemical composition & $\begin{array}{l}\text { Infrared spectrophoto- } \\
\text { motry pH and solids } \\
\text { content in accordance } \\
\text { with ASTM C } 494\end{array}$ & $\begin{array}{l}\text { Composite of each } \\
\text { shipment }\end{array}$ \\
\hline \multirow[t]{3}{*}{ Concrete } & $\begin{array}{l}\text { Mixer uniformity } \\
\text { Sampling method } \\
\text { Compression cylinders } \\
\text { Compression strength }\end{array}$ & $\begin{array}{l}\text { ASTM C } 94 \\
\text { ASTM C } 172 \\
\text { ASTM C } 31 \\
\text { ASTM C } 39\end{array}$ & $\begin{array}{l}\text { Initially and every } 6 \text { months } \\
\text { One set of } 2 \text { cylinders from } \\
\text { ach } 100 \mathrm{cu} \text { yd or a minimum } \\
\text { of } 1 \text { set per day for each } \\
\text { class of concrete given in } \\
\text { CB-5234.2 }\end{array}$ \\
\hline & $\begin{array}{l}\text { Slump } \\
\text { Air content } \\
\text { Temperature }\end{array}$ & $\begin{array}{l}\text { ASTMC } 143 \\
\text { ASTMC } 173 \text { or } \\
\text { ASTM C } 231\end{array}$ & $\begin{array}{l}\text { First batch placed each day } \\
\text { and every } 50 \mathrm{cu} \text { yd placed } \\
\text { First batch placed each day } \\
\text { and every } 50 \mathrm{cu} \text { yd placed } \\
\text { First batch placed each day } \\
\text { and every } 50 \mathrm{cu} \text { yd placed }\end{array}$ \\
\hline & Unit weightyield & ASTMC 139 & Daily during production \\
\hline
\end{tabular}

NOTE:

(1) Twice daily during production if more than $200 \mathrm{cu}$ yd are placed.

Table CB-5200-1 of Ref. 1. 
TABLE II

EXAMINATION METHODS FOR CRV COMPONENTS AND PARTS ${ }^{a}$

\begin{tabular}{cll}
\hline $\begin{array}{c}\text { Examination Areas } \\
\text { from Table IGK-2500 }\end{array}$ & \multicolumn{1}{c}{$\begin{array}{c}\text { Components and Parts } \\
\text { To Be Examined }\end{array}$} & Method \\
\hline A & Top head concrete surfaces & Visual \\
B & Bottom head concrete surfaces & Visual \\
C & Side wall concrete surfaces & Visual \\
D & Support structure & (Later) \\
E & $\begin{array}{l}\text { Unbonded prestressing anchor } \\
\text { assemblies }\end{array}$ & \\
& (a) Tendon wire/strand ends & Visual \\
& (b) Tendon anchor assemblies & Visual \\
& (c) Cover caps/plates over & Visual \\
& (d) Corrosion protection & Visuai \\
\hline
\end{tabular}

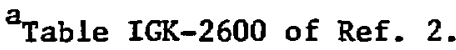

The in-service monitoring and surveillance requirenent; specify

(a) Monitoring of tendon prestress Iorces.

(b) Surveillance of vessel deflections.

(c) Surveillance of prestressing systems for corrosion attack.

(d) Surveillance of liner material for radiation effects.

The requirements of Section XI, Division 2 for in-service inspection of concrete pressure vessels thus specify visual examination (crack mapping) and instrumentation measurements. It becomes apparent from the code requirements that nondestructive inspection of prestressed concrete pressure vessels by other than visual methods is difficult, and monitoring and surveillance of critical parameters will yield results which assure safe operation of the structure. 


\section{PRACTICES IN CONSTRYCTION AND OPERATION OF GAS-COOLED REACTOR VESSELS}

Prestresseü concrete reactor vessels have been in operation since the mid-1960s, and much experience has been gained. However, only one such pressure vessel is in operation in the U.S., at the gas-cooled reactor in Fort St. Vrain, Colorado. This reactor uses helium as the coolant, while most others utilize $\mathrm{CO}_{2}$. The existing prestressed concrete pressure vessels differ in size and shape, but have one common feature: All are equipped with a water-cooled liner and insulation to reduce the temperature gradient through the concrete wall.

The design, construction, proof testing, and commissioning of prestressed concre ce pressure vessels $(4-31)$ in the U.S. and elsewhere proceeded along sinilar lines, often before any code requirements existed. The conceptual design was analyzed with computer modeling, and the results tested on instrumented scale models. The findings were used to formulate the final design, which took into account selection and placement of instrumentation to be embedded during construction. The construction often required unique equipment and detailed quaiity assurame to fulfill specification requirements. The number and type of instruments embedded in prestressed concrete pressure vessels vary from country to country and site to site. For example, 550 sensors were incorporated during the construction of the Fort St. Vrain pressure vesse1. The initial numbers and survival rates of the various instruments are shown in Table III. (11)

TABLE III

PCRV STRUCTURAL INSTRUMENTATION ${ }^{\mathrm{a}}$

\begin{tabular}{|c|c|c|}
\hline \multirow{2}{*}{ Sensor/Measurement } & \multicolumn{2}{|c|}{ Total No. of Sensors } \\
\hline & Installed & Functional* \\
\hline Load Cell on Tendons & 27 & 27 \\
\hline $\begin{array}{l}\text { Vibrating Wire Strain } \\
\text { (VWG Gage in Concrete) }\end{array}$ & 110 & 80 \\
\hline $\begin{array}{l}\text { Carlson Strain Gage in } \\
\text { Concrete }\end{array}$ & 25 & 20 \\
\hline $\begin{array}{l}\text { Weldable Strain Gage on } \\
\text { Rebar }\end{array}$ & 25 & 13 \\
\hline $\begin{array}{l}\text { Weldable Strain Gage on } \\
\text { Liner }\end{array}$ & 103 & 57 \\
\hline $\begin{array}{l}\text { Thermocouple (with VWG) } \\
\text { in Concrete }\end{array}$ & 69 & 60 \\
\hline Thermocouple on Liner & 166 & 155 \\
\hline $\begin{array}{l}\text { Moisture Monitor in } \\
\text { Concrete }\end{array}$ & 25 & 21 \\
\hline TOTAL & 550 & 433 \\
\hline
\end{tabular}


After five years of operation, $70 \%$ of the instruments are still operational and used for in-service surveillance. Additional visual inspections and crack mapping were done after construction and both before and after pressure testing. In some foreign concrete pressure vessels, crack growth was monitored with crack gauges and vessel deflections under pressure were measured with optical telescopes, Invar tapes, manometric equipment, and dial gavges. The results indicate a good correlation between measured and calculated values.

The instrumentation required for pressure testing of prestressed concrete pressure vessels is an integral part of the vessel and thus very suitable for in-service monitoring. Strain and temperature data are collected at regular time periods (every month at Wylfa, England), while moisture is measured at longer time intervals (four times a year at Wylfa). A large number of gauges were used in some of the earlier vessels in order to obtain detailed experimental data. This number was subsequently reduced for faster evaluation of results. Periodic mapping and measuring of surface cracks is another part of the in-service monitoring and surveillance practice. Tendon loads are checked periodically on a statistical basis ( $1 \%$ of total number), with accompanying visual examination of the concrete under the anchor plates. Samples of tendons or tendon wires are visually (and sometimes chemically) examined for corrosion attack, usually during tendon load surveys.

In-service monitoring and surveillance of prestressed concrete pressure vessels bore out that while the prestressing load is reduced somewhat by tendon relaxation and concrete creep, the load will remain above the minimum design level for the projected 30-year life span. Some slippage in the cable anchor system, breakage of tensioning cable strands, and movement of anchor plates into the concrete are also observed. In a single case (Dungeness, England), an abnormally high level of corrosion pitting of tendons was detected during plant construction. This corrosive attack was caused by water ingress into the ducts and subsequent emuisification of the corrosion-jreventing grease. Stress measurements after prolonged operation ( $>15$ years) indicane that the stress remains within predicted limics. Temperature data show that while the temperature distribution remains constant, some "hot" spots develop after a prolonged period of fuli-power operation. Crack mapping and crack-growth monitoring show some crack growth and appearance of new cracks, but these remain rather small; none hes reached dimensions requiring repair. Prestressed concrete pressure vessels equipped with moisture gauges exhibited no change in moisture content.

All in all, in-service monitoring and surveillance of prestressed concrete pressure vessels, as currently practiced, seems adequate to assure safe operation, as borne out by the fact that the first such vessel (Marcoule, France) has operated since 1960 without incident.

\section{DISCUSSION AND RECOMMENDATIONS}

Development of a code for prestressed concrete pressure vessels and actual design and construction of such a vessel in the U.S. proceeded almost simultaneously. All such vessels in the U.S. and abroad are instrumented for pressure proof testing, and the instrumentation is subsequently used for 
in-service monitoring and surveillance. The surveillance includes visual examination for surface cracks and tendon conditions. Implementation of inservice monitoring and surveillance has yielded satisfactory results to date, and use of additional inspection techniques would only increase costs and downtime.

Some concern exists regarding excessive leakage through concrete as a consequence of faulty construction (numerous voids), especially in containment vessels. Preliminary results abroad $(20)$ show the potential application of "sonic coring" tests to inspection of concrete pressure vessels. The sonic coring method utilizes low-frequency (50-100 kHz) ultrasound to inspect the concrete between two adjacent tendon tubes by measuring the time of flight of the ultrasonic pressure wave. The large number of tendons in a pressure vessel, and the necessity to fill the tendon tubes with water as a couplant, would make the inspection rather expensive and time-consuming. Ultrasonic through-transmission as a means of inspecting concrete structures was evaluated in the past $(32,33)$ with encouraging results. However, application of this method to prestressed concrete pressure vessels is destined to fail because of scattering by the multiple layers of tendons, and the limitations imposed by one-sided access. The same is true for radiographic examinations, where tackground radiation and the wall thickness will cause additional problems.

The adequacy of present in-service monitoring and surveillance indicates that attention should be redirected from development of new inspection methods to improvement of monitoring instrumentation and techniques. Areas which should be addressed include:

(a) Developing more robust strain gauges to ensure a higher rate of survival.

(b) Developing a technique and/or model to detect and compensate for erroneous gauge re:dings.

(c) Determining whether strain results are really required or whether stress gauges (such as Carlson and Glötzel gauges) or deflection- and movement-detection devices would yield arore relevant results.

(d) Determining whether the application of laser methods to measurements of dimensional changes would yield more accurate and consistent results than currently used manometric or optical systems.

Additionai efforts should be directed toward establisining (a) the optimum number and location of gauges for a given vessel design, (b) the best way to present data, and (c) data normalization methods that would facilitate performance comparisons among different prestressed concrete pressure vessels. 


\section{REFERENCES}

(1) AS:E Boiler and Pressure Vessel Code, Section III, Division 2, "Nuclear Fower Plant Components - Concrete Reactor Vessels and Containnents," ASME, 1977 Edition plus addenda.

(2) ASME Boiler and Pressure Vessel Code, Section XI, Division 2, "Inservice Inspection of Nuclear Power Plant Components - Rules for Inservice Insfection and Testing of Components of Gas-cooled Nuclear Power Plants," ASME, Draft Cl Edition, 1975.

(3) T. E. Northrup, The ACI-ASME Code for Concrete Reactor Vessels and Containments (USA), Proc. Conf. on Experience in the Desion, Construction, and Operation of Prestressed Concrete Pressure Vessels and Containments for Nuclear Reactors, York, U.K., Sept. 8-12, 1975, Mechanical Engineering Publications Ltd., London, p. 125.

(4) I. W. Hannah, Prestressed Concrete Pressure Vessels in the United Kingdom, ibia., p. 1 .

(5) R. Crowder, R. M. Howells, and A. A. Paton, Design and Construction of the Prestressed Concrete Boiler Closures for tho Hartlepool and Heysham Pressure Vessels, ioia., p. 145.

(6) A. J. Neylan, R. A. Barker, and A. F. Deardorff, Experience at Fort St. Vrain, ibia., p. 179.

(7) E. C. Smith and J. Kanthol, Jr., Leakage Testing of CANDU Containment, ioia., p. 185.

(8) T. E. Johnson, Testing of Large Prestressing Tencon Enc Anchorage Regions, ibia., p. 229 .

(9) S. J. Taylor and D. MCD. Eadie, Deveiopnent, Testing, and Installation of Prestressing of the PCPVs at Hinkley Point $B$ and Hunterston $B$, ibia., p. 261 .

(10) W. C. Jones and S. J. Taylor, Construction of the PCPVs at Hinkley Point B and Hunterston B, ijita., p. 271.

(11) F. S. Ople and A. J. Neylan, Construction, Testing, and Initial Operation at Fort St. Vrain PCRV, $3 \bar{i} \overline{6}$, p. 291.

(12) F. Bremer, Design and Construction of the PCPV for the 300 3Re THTR Nuclear Power Starion in Nest Germany, ijiz., p. 305.

(13) R. D. Browne, P. B. Banforth, and A. K. Welch, The Value of Instrumentation in the Assessment of Vessel Performance during Construction and Service, ibiç., p. 411 .

(14) D. McD. Eadie and D. J. Ball, Proof Pressure Tests of the PCPVs at Hinkley Point B and Hunterston B, $30 \hat{i}=$, p. 425. 
REFERENCES (continued)

(15) V. Brown and A. Bland, The Operator's View of the First Seven Years Service of the Concrete Pressure Vessels at oldbury-on-Severn Power Station, ibid., p. 435 .

(16) J. Irving, J. R. Smith, D. McD. Eadie, and I. W. Hornby, Experience of In-service Surveillance and Mfonitoring of Prestressed Concrete Pressure Vesse1s for Nuclear Reactors, $i b i d .$, p. 445 .

(17) N. Beaujoint and A. Guery, Experience in Operation and Inspection of Prestressed Concrete Pressure Vessels Belonging to Electricite de France, izid., p. 457 .

(18) T. Macken, J. B. Dee, and I. Davidson, PCRV Design and Develupment for the GCFR, isid., p. 489.

(19) R. M. W. Horner and A. Hodzic, A Prestressed Concrete Pressure Vessel for Helium High Temperature Reactor System, ibia., p. 499.

(20) S. A. Robertson, L. Duhoux, G. Dawrance, C. Carried and D. Morel, Method of Detecting Construction Faults in Concrete Pressure Vessels, ibid., p. 539 .

(21) R. Favre, M. Koprna, and J. P. Jaccoud, Transaction of the 4th International Conference on Structural Mechanics in Reactor Technology, San Francisco, August 15-19, 1977, Tests on Model of a Prestressed Concrete ivclear Pressure Vessel with Multiple Cavities, Paper $\mathrm{H} 4 / 2$.

(22) iv. S. Ottosen and S. I. Anderson, Structural Failure of Thick-walled Concrete Elements, ibid., Paper $\mathrm{H} 4 / 3$.

(23) K. Schimuelpfenning and G. Schnellenbach, New Experiences with Partial Prestressing of PCRV Based on Large Model Tests, ibid., , Paper H4/5.

(24) E. Funagalli, G. Verdelli, and F. L. Scotto, PCPV for BWR: Experimental Investigations up to Collapse of $1: 10$ Scale Model, $i b i d$. , Paper $\mathrm{H} 4 / 6$.

(25) S. Stock1, J. Neuner, and E. Grasser, Tests on Failure Mechanism of Thick Prestressed Concrete Rings with Inside Pressure, ioid., Paper $\mathrm{H} 4 / 8$.

(26) H. Geistefeldt, Material Law for Concrete Under Multiaxial Stress, ioid., Paper H5/1.

(27) H. Geistefeldt, Constitutive Equations for Cracked Reinforced Concrete Based on a Refined Model, ibia., Paper H5/2.

(28) D. A. Chapman and G. I. England, Effects of Moisture Migration on Shrinkage, Pore Pressure and Other Concrete Properties, $i \vec{b} i \vec{a}$., Paper H5/3. 
REFERENCES (continued)

(29) J. P. Rammant, L. van Laethem, and E. Backx, Steel Fiber Concrete, a Safer Material for Reactor Construction - A General Theory for Rupture Prediction, ibid., Paper H5/4.

(30) B. Kotulla and V. Hansson, The Design of Bonded Reintorcement for Temperature Stresses in Prestressed Concrete Reactor Vessels, ibid., Paper HS/5.

(31) D. J. Naus and J. P. Callahan, Embedment Instrumertation for Prestressed Concrete Pressure Vessels, ibid., Paper H5/6.

(32) H. T. Thorton, Jr., Development of Procedures for Nondestructive Testing of Concrete Strultures, Army Engineers Waterways Experiment Station Report WES-iP-C-77-1I-1 (September 1977).

(33) G. M. Pace and H. T. Thorton, Jr., Evaluation of the Soniscope for Nondestructive Testing of Portland Cement Concrete Pavements, Army Engineers Waterways Experiment Station AEkES-liscelìaneous Papers, Paper 6-806 (March 1966). 